ISSN: 2146-3042

DOI:

\title{
Yönetim Performans Ölçütlerinin Raporlanması: Avantajlar Ve Dezavantajlar*
}

\author{
Hakan CAVLAK**
}

\section{ÖZET}

Performans raporlaması, işletmelerin paydaşlarına faaliyetlerine ilişkin açıklama yaptıkları bir süreçtir. Geçerli finansal raporlama çerçevesi (Genel Kabul Görmüş Muhasebe İlkeleri-GKGMi, Uluslararası Finansal Raporlama Standartları-UFRS, vb.) haricinde oluşturulan ölçütler, son yıllarda bu raporlamada en çok kullanılan araçlardan biridir. Uluslararası Muhasebe Standartları Kurulu'nun aldığı geri bildirimler sonucunda bu tür ölçütlere ilişkin hazırladı̆̆ Yönetim Performans Ölçütleri taslağı, sağlayacağı avantajlar ve dezavantajları ile sıcak tartışma konularından birini oluşturmaktadır. Bu çalışmada, konu ile ilgili Amerikan Muhasebe Birliği, Avrupa Finansal Raporlama Danışma Grubu, Avrupa Menkul Kıymetler ve Piyasalar Otoritesi nin aralarında bulunduğu 11 uluslararası kurum, 4 büyük denetim şirketi ile Kати Gözetimi Kurumu'nun yorum mektupları nitel yöntem ve içerik analizi çerçevesinde incelenmiştir. Çalışmanın sonuçlarına göre taslak, çoğu kurum tarafindan desteklenmekte ve kullanıcılara fayda sağlayacağı ifade edilmektedir. Ancak taslak ile ilgili bazı endişeler de mevcuttur. Kamusal iletişim ifadesi, ölçütlerin kapsamının sadece kâr veya zarar ve diğer kapsaml gelir tablosunda sunulan gelir ve gider alt toplamlart ile sinılandırılmast, denetim, mutabakat gibi hususlar taslağın en çok eleştirilen ve tekrar gözden geçirilmesi talep edilen noktalarıdır.

Anahtar Kelimeler: Performans Raporlaması, Finansal Raporlamada Daha İyi İletişim, Yönetim Performans Ölçütleri, IASB, KGK.

JEL Sinıflandırması: M40, M49, L25.

\section{Reporting Management Performance Measures: Advantages and Disadvantages}

\section{ABSTRACT}

Performance reporting is a process in which businesses demonstrate their activities to their stakeholders. One of the most commonly used methods of performance reporting in recent years is the measures created outside of the current financial reporting framework (Generally Accepted Accounting Principles-GAAP, International Financial Reporting Standards-IFRS, etc.). About these measures, the International Accounting Standards Board (IASB) has also drafted Management Performance Measures (MPM). The draft, with its advantages and disadvantages, constitutes one of the hot topics of discussion. In this study, the comment letters of 11 international institutions (American Accounting Association, European Financial Reporting Advisory Group, European Securities and Markets Authority and others), the Big Four accounting firms and the Public Oversight Authority about MPM were examined within the framework of qualitative method and content analysis. According to the results of the study, the MPM draft is supported by most institutions and it is stated that it will benefit financial statement users. However, there are some concerns regarding the MPM draft. Issues such as the expression of public communications, restricting the reach of the MPM only to subtotals of income and expenses in the statement of profit or loss and other comprehensive income, audit and reconciliation are the most criticized points of the draft.

Keywords: Performance Reporting, Better Communication in Financial Reporting, Management Performance Measures, IASB, POA.

Jel Classification: M40, M49, L25.

* Bu makale, 23-25 Nisan 2021 tarihleri arasında gerçekleştirilen VI. Uluslararası Muhasebe ve Finans Sempozyumunda bildiri olarak sunulmuştur.

Makale Gönderim Tarihi: 06.05.2021, Makale Kabul Tarihi: 23.05.2021, Makale Türü: Nitel Araştırma

** Arş. Gör. Dr., Ardahan Üniversitesi İktisadi ve İdari Bilimler Fakültesi, hakancavlak@ardahan.edu.tr, ORCID: 0000-0002-5891-7722. 


\section{GíRiş}

İşletme yönetimleri düşük seviyede seyreden ya da Covid-19 gibi kriz ve belirsizlik zamanlarında etkilenen performansını daha iyi göstermek adına paydaşlarına sundukları performans rakamları üzerinde muhtelif düzeltme işlemleri yapabilmektedir. Bunun için ise geçerli finansal raporlama çerçevesi dışındaki alternatif performans ölçütlerine başvurmaktadırlar. İşletmelerin bu türden bir yol izlemelerinin temel nedeni, bu dönemlerde işletmelerin tek seferlik, tekrar etmeyen veya olağandışı olarak nitelendirilen durumlara maruz kalması ve bunların performans üzerindeki etkisinin giderilerek işletme performansının paydaşlara daha gerçekçi bir şekilde sunulma isteğidir. Ancak bu tür ölçütlere yönelik eğilim finansal tablo kullanıcılarının şüpheciliğini de artırmaktadır. Bunun nedeni, bu tür ölçütlerin açık ve şeffaf açıklamalar ile birlikte sunulmadığında kullanıcıları yanıltma riskine sahip olmasidır (Ernst \& Young, 2020a: 2; Sheridan vd., 2020; Tokar ve Kumar, 2020: 5).

"Geçerli finansal raporlama çerçevesi (GKGMİ, UFRS, vb.) haricinde oluşturulan performans ölçütleri, uluslararası standartlara sahip bir kılavuz çerçevesinde mi hazırlanmalıdır?" sorusu, bu çalışmayı ortaya çıkarmıştır. Sorunun, araştırmanın amacı olan Uluslararası Muhasebe Standartları Kurulu (International Accounting Standards Board IASB) tarafından hazırlanan Yönetim Performans Ölçütleri (Management Performance Measures - MPM) taslağının ortaya çıkaracağı avantajların-dezavantajların belirlenmesi ile yanıtlanması hedeflenmektedir. Araştırmanın kapsamını MPM taslağı ile ilgili uluslararası kurumların, denetim şirketlerinin ve Kamu Gözetimi Kurumu'nun (KGK) yorum mektupları oluşturmaktadır.

Çalışmada, öncelikle performans raporlaması, UFRS harici ölçütler, IASB'nin "Finansal Raporlamada Daha İyi İletişim" projesi, "Temel Finansal Tablolar" çalışması ve "Yönetim Performans Ölçütleri” ile ilgili bilgilere yer verilmektedir. Daha sonra ise IASB'nin MPM taslağı hakkında 16 kurumun yorum mektupları analiz edilmektedir. Son kısımda ise bulgulardan hareketle MPM taslağının avantajları ve dezavantajları yorumlanmaktadır.

\section{LITERATÜR}

$\mathrm{Bu}$ bölümde literatürde, performans raporlamasında yönetim performans ölçütlerinin nasıl ele alındığı açıklanmakta, IASB'nin bu ölçütlere ilişkin hazırladığı taslağın hangi proje kapsamında yer aldığına ve ölçütlere ilişkin ilkelere değinilmektedir.

\subsection{Performans Raporlaması}

İşletmelerin faaliyetlerine ilişkin sonuçları (ağırlıklı olarak finansal sonuçlar) paydaşlarına sunma aracı olarak tanımlanabilecek performans raporlaması şeffaflık, etkili yönetim ve hesap verebilirliğin önemli bir parçasıdır. Performans raporlaması, işletme faaliyetleri ile ilgili bir sonraki faaliyet döneminde mümkün olan en iyi kararı vermek için önemli bilgiler sağlar ve sürekli iyileştirme adına da geri bildirim döngüsünü destekler (Treasury Board Secretariat, 2008: 2). Bu katk1lar kurumsal performans raporlamasını günümüzde daha önemli hale getirmiştir. Bu önemin bir diğer nedeni kurum faaliyetlerinin sonucunun tüm paydaşları ilgilendirmesi ve paydaşların bilgi ihtiyaçlarını bu raporun karşılamasıdır. Geniş bir çerçeveyi ilgilendiren ve şeffaflığın önemli bir aracı olan performans raporlaması, açıkça uluslararası bir konudur ve ilgili tüm kurumların çalışma alanı 
içerisindedir (Bamber, Jiang, Petroni ve Wang, 2010: 106; Karmańska, 2014: 74; Thinggaard vd., 2006: 37).

Performans raporlaması, on beş yılı aşkın süredir giderek artan bir oranda Finansal Muhasebe Standartları Kurulu (FASB) ve IASB başta olmak üzere ilgili tüm uluslararası kurum ve kuruluşların gündemindedir (Smith, 2018: 2). Performans raporlamasındaki ilk önemli adım, 2004 yılında IASB ile FASB arasında ortak olarak başlatılan ve işletme performansının kullanıcılara daha iyi anlatılmasını amaçlayan "Performans Raporlama Projesi" olarak gösterilebilir. $\mathrm{Bu}$ proje sayesinde işletme performansının raporlanması hususunda önemli ilerleme kaydedilmiştir (Mısırlığlu, 2006: 23).

IASB'nin geçmişte bilançoyu temel alan bir muhasebe yaklaşımı benimsemesinin performans raporlamasının ikinci planda kalmasına neden olduğu ifade edilmektedir. İlerleyen süreçte IASB kapsamlı gelir kavramını kavramsal çerçeve bünyesine dahil ederek performans raporlamasına verdiği önemi artırmıştır (Gökten, 2019: 491). Özellikle son on yıllık süreçte ise finansal tablo kullanıcılarının değişen bilgi talepleri, piyasaların farklı bilgi talebi oluşturacak düzeyde gelişim göstermesi gibi sebepler, hem performans raporlamasının en önemli unsuru olan finansal performans tablosunda hem de kullanılan performans ölçütlerinde değişimi zorunlu hale getirmiştir. IASB başkanı Hoogervorst, önümüzdeki y1llarda performans raporlamasının ve bunla bağlantılı hususların kurulun önemli gündem konularından biri olacağını ve bu konuda ilerleme kaydetmek için akademisyenler başta olmak üzere tüm paydaşlarının katılımının önemli olduğunu vurgulamaktadır (Hoogervorst, 2016b: 3).

\subsection{Genel Kabul Görmüş Muhasebe İlkeleri/Uluslararası Finansal Raporlama Standartları Harici Ölçütler}

Bir işletmenin performansını gösteren sihirli sayı nedir? Bu soru dünyanın dört bir yanındaki muhasebe standardı belirleyicilerinin cevaplamakta tam anlamıyla başarılı olamadıkları bir sorudur. Bu soruya net bir cevabın verilememesi finansal tablo kullanıcilarını alternatif yollar aramaya ve bunları işletmelerden talep etme noktasına getirmiştir (Bouvier, 2018). Bu talep karşısında işletmelerin kullandıkları performans ölçütleri literatürde; Alternatif Performans Ölçüleri (APM-Alternative Performance Measures), Yönetim Performans Ölçütleri (MPM-Management Performance Measures), GKGMİ harici Performans Ölçütleri (Non-GAAP Performance Measures), UFRS harici Performans Ölçütleri (Non-IFRS Performance Measures), Alternatif/Düzeltilmiş Kazanç Ölçütleri (Alternative/Adjusted Earnings Measures) ya da Ek Performans Ölçütleri (Additional Performance Measures) olarak isimlendirilmektedir (Elisabetta ve Claudio, 2020: 95; Ernst \& Young, 2018: 3).

Günümüzde pek çok şirket, piyasa ve paydaşları ile iletişiminde işletmenin geçerli finansal raporlama çerçevesi haricinde hazırladıkları performans ölçütlerine başvurmaktadır. $\mathrm{Bu}$ ölçütler, işletme yönetimleri tarafindan geçerli finansal raporlama çerçevesi ya da Genel Kabul Görmüş Muhasebe İlkeleri (GKGMİ) doğrultusunda hazırlanan performans ölçütlerine ek olarak işletmenin finansal performansı, finansal durumu ve nakit akışları hakkındaki bilgileri kullanıcılara iletmek adına kullanılmaktadır. Ayrıca ilgili ölçütler, son yıllarda ulusal ve uluslararası düzeyde çok sayıda şirketin kamuoyuna sundukları finansal raporlara ek olarak performanslarını raporlarken kullanılmaktadır (CA ANZ, 2020; MIA, 2019: 1). 
Performans ölçütleri ister geçerli finansal raporlama çerçeveleri içerisinde isterse de bunların haricinde açıklansın temel amaç finansal tablo kullanıcılarına işletmenin performansı hakkında faydalı bilgi sağlamaktır (Alibhai vd., 2019: 54). Dünyadaki büyük şirketlerin çoğunun halihazırda GKGMİ harici ölçütler kullanmasının temel nedeni söz konusu ölçütlerin işletmenin performansı hakkında daha net bir resim ortaya koyması olarak ifade edilmektedir (Deller, 2019). Şirketler de GKGMI harici bilgi sunmanın kendi hikayelerini anlatmalarına olanak tanıdığını ve paydaşlarına şirketin performansı hakkında yararlı bilgiler sağladığını ifade etmektedir. Sonuçta hem sunan hem de kullanan açısından GKGMİ harici ölçütler faydalı görülmektedir (Kegalj, 2020: 2; Shibasaki ve Toyokura, 2020: 23).

GKGMİ harici ölçütlerin oluşturulmasında temel işlem GKGMİ'ye göre hazırlanan rakamların düzeltme işlemine tabi tutularak işletme performansını daha net gösteren rakamların ortaya konmasıdır (Deller, 2018). Örneğin, GKGMİ veya geçerli finansal raporlama çerçevesine göre hesaplanan kar rakamı, şirketler arasında karşılaştırılabilir olduğu için yatırımcılar arasında önemli bir ölçüttür. Ancak yatırımcılar bu rakamın yanında şirket performansını daha gerçekçi bir şekilde yorumlamak adına düzeltilmiş kar rakamlarını da talep etmektedir (Sheridan ve McCarroll, 2020: 59). Bazı yaygın GKGMİ harici ölçütler arasında düzeltilmiş gelirler, düzeltilmiş kazançlar, düzeltilmiş hisse başına kazançlar, düzeltilmiş faiz, amortisman ve vergi öncesi kâr (FAVÖK) gösterilebilir (Sherman ve Young, 2018). IASB'nin gerçekleştirdiği bir araştırmada (Borsada işlem gören 100 şirketin 20172018 yıllık raporlarının analizinde), en yaygın UFRS harici ölçütler olarak düzeltilmiş kar (\%33), düzeltilmiş faaliyet karı (\%29), düzeltilmiş FAVÖK (\%20), düzeltilmiş FVÖK (\%11) kullanıldığı belirlenmiştir (Ryan, 2019).

Son yıllarda konu ile ilgili yapılan araştırmaların bir sonucu, UFRS harici ölçütleri kullanmayan şirket bulmanın artık zor olduğudur (The Footnotes Analyst, 2020). Binlerce halka açık şirketin finansal tabloları ve diğer iletişim araçları incelendiğine dikkate değer bir eğilim görülmektedir. Bir zamanlar kabul edilebilir bir şekilde kullanılan ve çoğunlukla küçük bir yatırımcı grubuyla paylaşılan alternatif ölçütler, daha yaygın hale gelmiştir. Ancak bazı kesimlere göre ölçütler gerçeklikten uzak bir yapıya doğru yol almaya başlamıştır. Örneğin, 2011 yılında Groupon Inc., merakla beklenen ilk halka arz planlarını açıklarken kullandığı "adjusted consolidated segment operating income" isimli GKGMİ harici ölçüt hakkında ABD Menkul Kiymetler ve Borsa Komisyonu (U.S. Securities and Exchange Commission - SEC), bu ölçütü sorgulayan bir yorum mektubu yayınladı. Bunun sonucunda halka arz teklifine talep azaldı. Bunun nedeni, ölçütün daha önce hiçbir şirket tarafından kullanılmaması ve işletmenin 2010 gelir tablosunda rapor edilen faaliyetlerden 420 milyon dolarlık bir zarar1 60 milyon dolarlık bir kazanç olarak göstermesidir (Sherman ve Young, 2018: 60).

UFRS harici ölçütlerin bir işletmenin finansal performansı hakkında yararlı bilgiler sağlayabileceği, ancak yine de yukarıda yer alan örnek gibi benzeri durumlardan hareketle bu ölçütlere ilişkin şeffaflık ve disiplin (netlik, tam açıklama vb.) iyileştirilmelerinin yapılması gerektiği hem IASB hem de kullanıcılar tarafından ifade edilmektedir (Elisabetta ve Claudio, 2020: 102; IFRS Foundation, 2019b: 37; Liikanen, 2019: 17). GKGMİ harici ölçütler doğru kullanıldığında, yatırımcılara bir şirketin finansal performansı ve durumu hakkında yararlı ek bilgiler sağlamakta ve GKGMİ rakamlarını tamamlamaktadır. Bununla birlikte, konu ile ilgili otoriteler arasında bu ölçütlerin kullanımı, sunulması ve raporlanmasında çeşitlilik bulunmaktadır (Bogle, 2017; The CPA Journal, 2018: 16). 
Avrupa Menkul Kıymetler ve Piyasalar Otoritesi (ESMA) ve IASB başta olmak üzere uluslararası kurum ve kuruluşlar, finansal olmayan bilginin, elektronik raporlamanın ve GKGMİ harici performans ölçütlerinin gündemlerinin ön sıralarında yer alacağını ifade etmektedir (Grant Thornton, 2018: 3). SEC ve ESMA gibi çoğu düzenleyici kurum, finansal raporlara GKGMİ harici ölçütlerin dahil edilmesini kapsayan düzenlemeler yayınlamıştır. Bu düzenlemelerde temel kural, ölçütlerin yanıltıcı olmayacak şekilde etiketlenmesi ve doğrudan birincil finansal tablolardan çıkarılan ölçütlerden daha belirgin bir şekilde gösterilmemeleridir (Muc, 2020).

IASB ise başlangıçta söz konusu ölçütlere olumsuz bir bakış açısı ile yaklaşmaktaydı. Ancak daha sonraki süreçte hem ölçütlerin kullanımının yaygınlaşması hem ölçütlere ilişkin paydaşlardan gelen talepler hem de UFRS çerçevesinde sunulan ölçütlere olan algının farklılaşması gibi nedenler ile konuyla ilgili düzenleme yapmanın zorunlu hale geldiği ifade edilmeye başlandı. Bu çerçevede ilgili ölçütlere ilişkin çalışma yapma fikri ilk olarak 2013'te ortaya atılmış 2017 yılında ise çalışmanın IASB'nin “Finansal Raporlamada Daha İyi İletişim” projesi içerisinde yer almasına karar verilmiştir.

\subsection{Finansal Raporlamada Daha İyi İletişim Projesi}

Finansal tablo kullanıcıları tarafından IASB'ye finansal tablolar ile ilgili ağırlıklı olarak "ihtiyaca uygun yeterli bilginin olmaması", "ihtiyaca uygun olmayan çok fazla bilginin olması" ve "etkisiz iletişim-ihtiyaca uygun bilginin etkili sunulamaması" hususlarında yapılan geri bildirimler, IASB'nin Şekil 1'de görülen formülün ve "Finansal Raporlamada Daha İyi İletişim” projesinin ortaya çıkmasını sağlamıştır (Flores, 2019: 22):

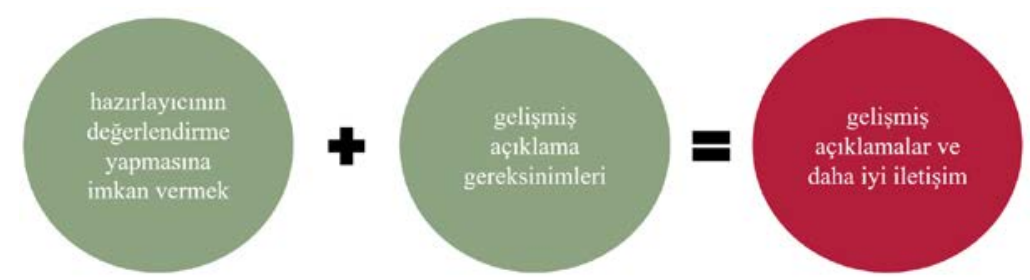

Şekil 1. "Finansal Raporlamada Daha İyi İletişimı” Projesini Ortaya Çıkaran Formül Kaynak: Flores, 2019: 22

Odak noktası, finansal performans tablolarının (kâr veya zarar ve diğer kapsamlı gelir tablosu) sunumunu iyileştirmek olan "Finansal Raporlamada Daha İyi İletişim” projesi; işletmeye özgü, basit ve doğrudan, birbiriyle daha bağlantılı açıklamalar sunan, daha etkili formata sahip, mükerrerlikten kaçınan, karşılaştırılabilirliği artıran bir raporlama düzeyine ulaşılmasını amaçlamaktadır. Proje, yatırımcılar ile hazırlayıcılar arasında özellikle finansal performans tablosunu yeniden şekillendirmeye odaklanan önemli bir tartışma alanıdır (FINFSA, 2019: 2; Stewart, 2020; Sultanoğlu, 2020: 234).

“Finansal Raporlamada Daha İyi İletişim” projesine ilişkin olarak IASB Başkanı Hans Hoogervorst, "çalışmaların, finansal tabloların karşılaştırılabilirliğinde ve kullanışlılığında bir oyun değiştiriciyi temsil ettiğini" belirtmektedir (Hood, 2019; Hughes, 2020). IASB Başkan Yardımcısı Sue Lloyd da proje kapsamında yürütülecek çalışmaların finansal raporlamayı güçlendirmeyi amaçladığını ifade etmektedir (Grant Thornton, 2019: 4). 
IASB yukarıda ifade edilen üç temel geri bildirimin sonucunda 2017-2021 yılları arasını kapsayan beş yıllık bir çalışma planı ortaya koymuştur. Finansal bilgilerin daha kullanılabilir şekle getirilmesine yardımcı olmak ve finansal bilgilerin kullanıcılara aktarılmasını geliştirmek için tasarlanan planın unsurları ise Şekil 2'deki gibi belirlenmiştir. Projenin ve içerisinde yer alan hususların, IASB'nin önümüzdeki yıllarda ajandasındaki çoğu çalışmanın odağında yer alması ve bunlara yön vermesi düşünülmektedir (IFRS Foundation, 2017: 5).

\section{Finansal Raporlamada Daha İyi İletişim}

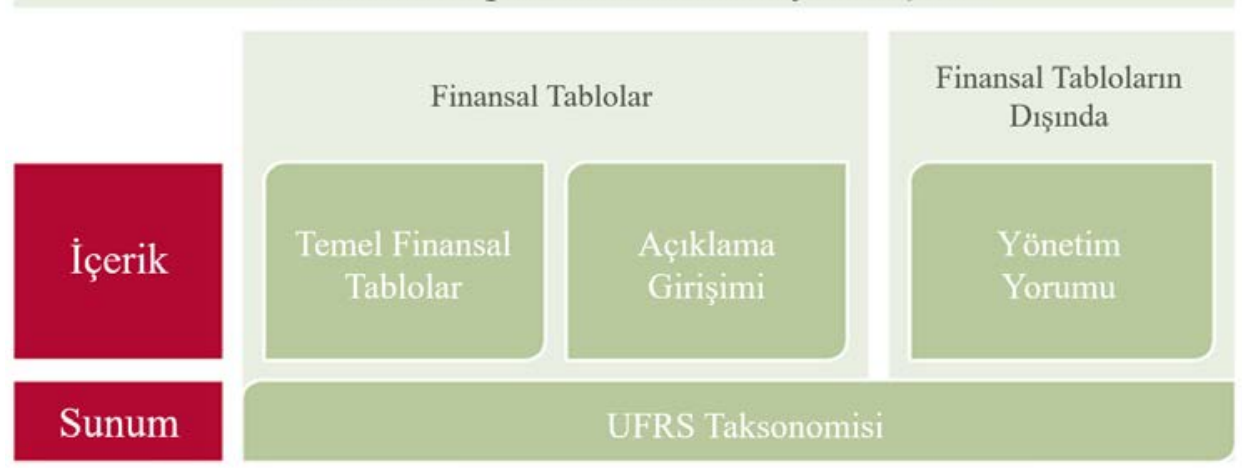

Şekil 2. IASB “Finansal Raporlamada Daha İyi İletişim” Projesi

Kaynak: www.ifrs.org/projects/better-communication/\#about (Erişim: 10.01.2021)

Şekil 2'de görüldüğü üzere IASB'nin yürüttüğg̈ proje, içerik olarak üç (Temel Finansal Tablolar, Açılama Girişimi, Yönetim Yorumu), sunum halindeki bir (UFRS Taksonomisi) çalışmadan oluşmaktadır. Açıklama girişimi çalışması, dipnotların içeriğinde ve etkili sunumunda önemli iyileştirmeler yapılmasını; yönetim yorumu çalışması, işletmenin finansal tabloları için ek bilgiler sağlayan finansal raporların birincil kullanıcılarını (yatırımcılar, kedi verenler, vb.) hedefleyen açıklayıcı bir raporun oluşturulmasını; UFRS taksonomisi çalışması da proje kapsamında oluşturulan tüm içeriğin ilgililere elektronik olarak raporlanmasını hedeflemektedir. $\mathrm{Bu}$ çalışmada, UFRS harici ölçütlerin incelenmesinden dolayı bu ölçütlerin yer aldığı "Temel Finansal Tablolar" çalışması ile ilgili hususlar detaylandırılmaktadır.

Temel finansal tablolar ve dipnotlarda yer alan bilgiler kullanıcıların, denetçilerin, düzenleyicilerin işletme faaliyetlerini aktarmada ve anlamada kullandıkları en önemli iletişim aracıdır (Deloitte, 2017: 3; Sivanantham, 2016: 1). Bu çerçevede finansal tablo kullanıcılarına yardımcı olmak adına karşılaştırılabilirliği artırmak, daha net açıklama üretmek, kullanıcılar için finansal tabloların açıkça anlaşılabilir bir resmini oluşturmak ve finansal performans hakkındaki bilgilerin raporlanmasını iyileştirmek amacı ile IASB ilgili çalışmayı yürütmektedir. Kurum, finansal tabloların yapısında ve içeriğinde iyileştirmeler sağlamayı hedeflemektedir. Çoğu otorite IASB'nin başlattığı bu çalışmayı çok değerli olarak nitelendirmektedir (Deller, 2020; EFRAG, 2020: 2; IFRS Foundation, 2019c; Knight, 2020).

“Finansal Raporlamada Daha İyi İletişim” projesinin bir parçası olan "Temel Finansal Tablolar" çalışması, finansal tablo kullanıcılarının performans raporlaması konusundaki güçlü taleplerine yanıt vermek istemektedir (IFRS Foundation, 2019b: 38). Proje kapsamında kurul, özellikle hem işletmelerin finansal tablolarını hazırlayanlardan hem de finansal tabloları 
analiz eden kullanıcılardan önemli geri bildirimler almıştır. IASB'nin temel finansal tablolar çalışmasına ilişkin paydaşlardan gelen geri bildirimler ve bunlara istinaden ortaya konan temel çözüm önerileri Şekil 3'teki gibidir (Flores, 2019: 16; Sultanoğlu, 2020: 234).

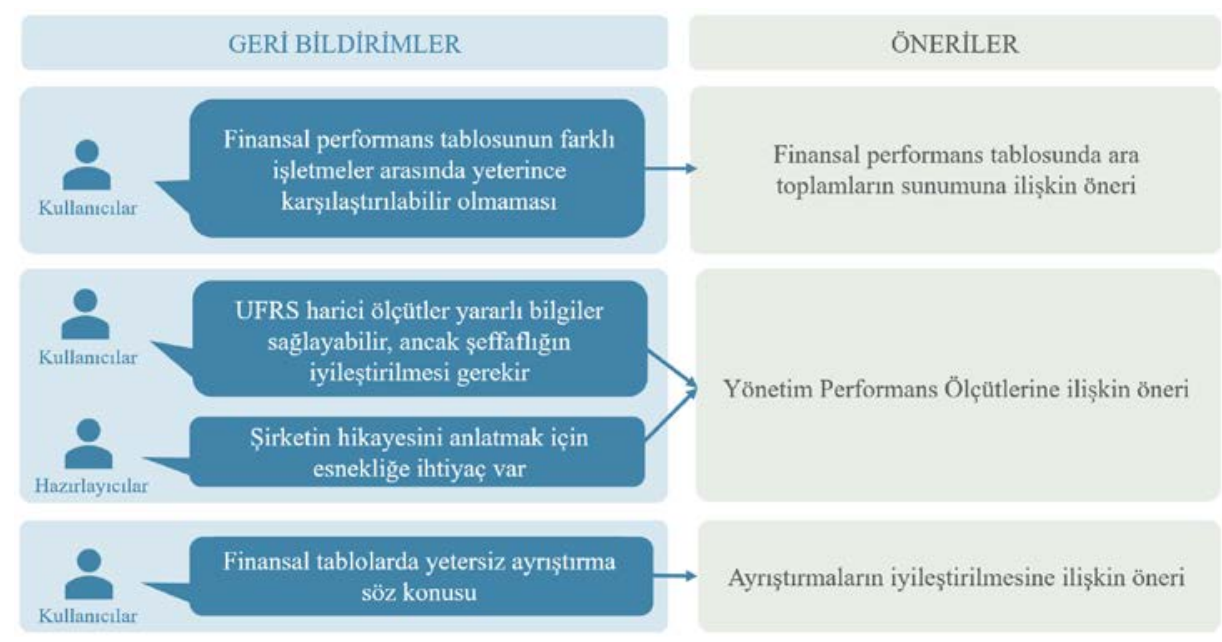

Şekil 3. Paydaşların Geri Bildirimleri ve Çözüm Önerileri Kaynak: Flores, 2019: 16

“Temel Finansal Tablolar” çalışması içindeki en temel iki konu; finansal tablolardaki alt/ara toplamlar ile yönetim performans ölçütleridir. Bu kapsamda çalışma ile ayrıca, dipnotların iyileştirilmesi ile işletme performansının karşılaştırılabilirliğinin artırılması amaçlanmakta ve özellikle nakit akış tablosu ile gelir tablosunda güncellemelerin yapılması planlanmaktadır (Bölükbaş, 2019: 1353; Ernst \& Young, 2018: 3).

IASB'nin UFRS harici ölçütler konusunda çalışma yürütmeye karar vermesini zorunlu hale getiren temel neden, bu ölçütlere ilişkin endişelerin giderek artmasıdır (Maurer, 2019; Meteil-Dutartre, 2020). IASB, kendi oluşturacağı UFRS harici ölçüt kılavuzu ile bu ölçütlere ilişkin yaşanan bazı ihlallerin ve endişelerin azaltılabileceğini düşünmektedir. Bu bağlamda IASB bu ölçütlere başlangıçta karşı çıksa da daha sonraları "onları yenemezseniz, onlara katılın" ("if you can't beat them, join them") yaklaşımını benimsemiştir. Bunun da bir sonucu olarak proje amaçlarının gerçekleştirilmesine yardımcı olma amacı ile bu çalışmanın da kapsamında yer alan Yönetim Performans Ölçütleri çalışması oluşturulmuştur (Akinwale ve Donkersley, 2018: 10; Clinch, Tarca ve Wee, 2019: 3; Westworth Kemp, 2019).

\subsection{Yönetim Performans Ölçütleri (Management Performance Measures - MPM)}

İşletme yönetimleri işletmenin performansına dair paydaşlarına bilgi sunarken Şekil 4'te yer alan ölçüt ve göstergelerden yararlanmaktadır (Lange, Voilo ve Feygina, 2020: 14): 


\section{Yönetim Ölçütleri ve Göstergeleri}

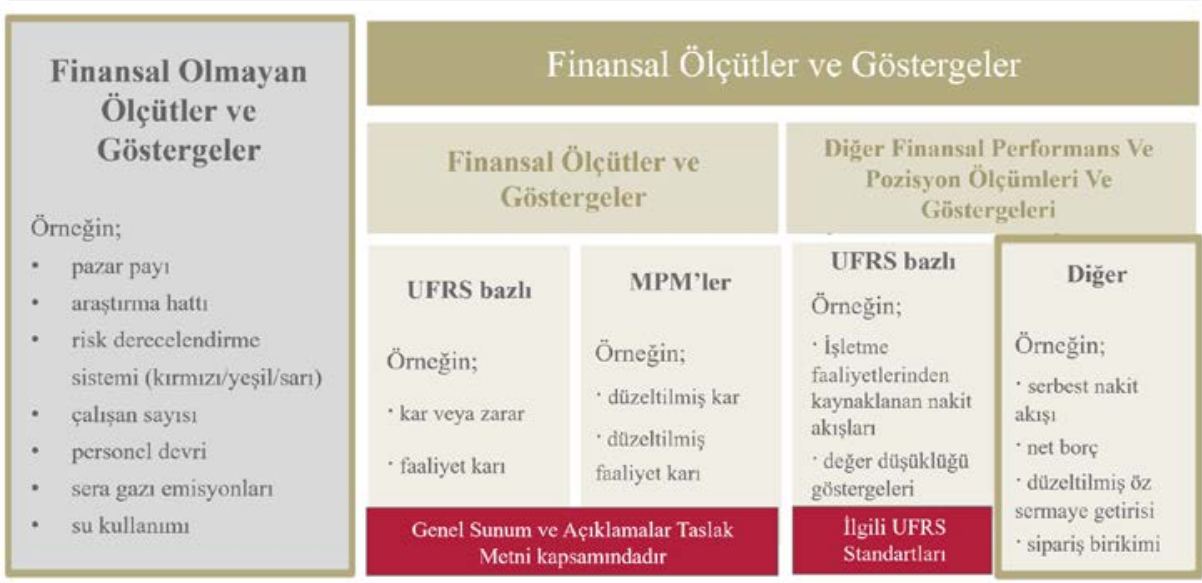

Şekil 4. Yönetim Tarafından Kullanılan Ölçütler ve Göstergeler

Kaynak: Lange vd., 2020: 14

IASB'nin performans ölçütlerine ilişkin bakış açısını özetleyen Şekil 4'te görüldüğü üzere MPM'ler finansal ölçütler içerisinde ancak UFRS harici olarak görülmektedir. MPM'lere finansal olmayan bilgilerin (şube sayısı, çalışan sayısı, vb.) de eşlik ederek işletmenin finansal performansının bir yönüne ilişkin yönetimin görüşünü sağlayan ölçütlerin (şube başına ortalama net gelir gibi) de dahil olup olmayacağı IASB tarafindan netleştirilmesi istenen hususlardan biridir (Kadlecová, 2020). IASB'nin görüşüne göre UFRS harici ölçütler, genel olarak finansal olmayan bir ölçüyü (örneğin; pazar payı, personel devir sayısı, çalışan başına satılan birim sayıs1, vb.) veya ileriye dönük öngörüleri (örneğin, yönetimin gelecekteki satışlar ile ilgili beklentileri, vb.) ifade etmemelidir (Fisher, 2018: 7). Bu sebeple de IASB MPM’leri sonuçlanmış (geçmiş dönemin) finansal ölçütlerden sadece kâr veya zarar ve diğer kapsamlı gelir tablosunun unsurları olan gelir ve giderlerin alt toplamları ile sınırlandırmıştır.

İlk zamanlarda IASB, UFRS harici ölçütleri finansal tablo kullanıcılarının tüketmesi için kolay ve faydalı ancak yanıltıcı olduğunu ifade etmekteydi. Bu endişenin bir nedeni halihazırda UFRS dahilinde hesaplanan rakamların gerçeğe uygun değer ve benzeri konularda eleştiri altında olması ve böyle bir zamanda MPM'lerde yapılacak düzeltme işlemlerinin güvenilirliği ve şeffaflığı bozabileceğidir (Grant Thornton, 2020: 3; Young, 2014: 446). Daha sonraları ise UFRS harici ölçütlerin işletmeye değer katabileceği ve kurulun bu ölçütlerin kullanımına dair temel bir itirazının olmadığı ifade edildi. Ancak bu ölçütlerin işletme performansını pembe bir resim şeklinde çizme eğiliminde olması (Hoogervorst, bu ölçütler için yapılan düzeltmeleri "şeker kaplı düzeltmeler" olarak nitelendirmiştir.) ve UFRS rakamlarından daha iyi sonuçlar ortaya koyması, kurulun ölçütlere daha ihtiyatlı ve dikkatli yaklaşmasını sağladı (Hoogervorst, 2015: 3, 2016a: 4, 2019: 2; Sweet, 2016).

Hoogervorst'un, oyunun kurallarını değiştirecek bir çalışma olarak nitelendirdiği MPM taslağı hazırlanırken muhtelif paydaşlara danışılmış ve onlardan söz konusu teklifin yatırımcıların şirket performansını analiz etmek için ihtiyaç duydukları bilgileri daha kolay bulmalarına yardımcı olup olmayacağı hakkında geri bildirimler alınmıştır. Dolayısıyla ilgili taslak hazırlayıcılar, kullanıcılar, denetçiler ve düzenleyiciler dahil olmak üzere tüm ilgili 
tarafların katılımını içermektedir (Ernst \& Young, 2020b: 4; Institute of Directors, 2020; Morgan, 2020).

IASB Başkanı Hoogervorst "MPM ile yönetim performans ölçütleri konusunda şeffaflı̆̆ın artacă̆l ve yatırımcıların istedikleri bilgiyi bulmasının daha kolay hale geleceği”" değerlendirmesinde bulunmuştur (White, 2019). Huawei Finansal Raporlama Kıdemli Uzmanı Michael Stewart, IASB'nin konu ile ilgili çalışmasını "Şirketlerin, performanslarını en iyi ifade ettiğini düşündükleri ölçütleri kullanarak kendi hikayelerini anlatmalarına izin verilmesi” olarak nitelendirmektedir (ICAEW, 2020).

MPM taslağındaki ilkeler, ESMA Alternatif Performans Ölçütleri (Alternative Performance Measure - APM) Rehberi ile geniş ölçüde uyumludur (Kegalj, 2020: 2). Bu nedenle MPM taslağının, ESMA APM kılavuzundaki ilkelerin anlaşılabilirliğini artırması beklenmektedir (Jana ve McMeeking, 2020: 31). Ancak bununla birlikte konu hakkında bir karışıklık oluşabileceği görüşü de mevcuttur (EFRAG Secretariat: PFS team, 2020: 2). MPM ile APM arasında birtakım farklılıklar söz konusudur. MPM'lerin kapsamı (sadece gelir ve giderlerin alt toplamı) APM'lerden (gelir, gider, finansal durum, nakit akış, vd.) daha dardır. İki düzenleme de mutabakat gerektirmekte, ancak kapsamı farklılaşmaktadır. MPM her durumda en doğrudan karşılaştırılabilir bir mutabakat isterken APM bazı durumlarda mutabakat istememektedir (EFRAG Secretariat: PFS team, 2020: 3).

IASB'nin MPM taslağındaki açıklama gereksinimleri, ESMA APM Kılavuzu dışında SEC GKGMİ harici ölçütlerinin sunumuna ilişkin kuralları (Regulation G, Regulation S-K, Compliance and Disclosure Interpretations) ile de benzerlik göstermektedir (Shearman ve Sterling LLP, 2020). MPM’lerin yürürlükteki benzer düzenlemelerden en temel farkı ve en çok eleştirilen özelliği bu ölçütlerin sadece kâr veya zarar ve diğer kapsamlı gelir tablosundaki gelir ve gider alt toplamları ile sinırlandırılmasıdır (Paulech, Locke ve Gladchenko, 2020: 2) ki ilgili durum bu çalışmanın bulguları içerisinde de görülmektedir. MPM dışındaki ESMA ve SEC düzenlemelerinde ölçüt kapsamı kâr veya zarar ve diğer kapsamlı gelir ile sınırlandırılmamakta diğer finansal tablo unsurları da kullanılabilmektedir.

MPM dışındaki GKGMİ harici ölçütlere ilişkin var olan düzenlemelere göre oluşturulan ölçütler finansal tabloların dışında ayrı bir not olarak sunulduğundan doğrudan denetime tabi değildir. MPM taslağının yürürlüğe girmesi ile ölçütlerin UFRS'ye göre hazırlanan finansal tabloların bir parçası olması ve dolayısıyla denetime tabi olmaları beklenmektedir. Bu ölçütleri MPM ile denetime tabi kılmanın daha fazla küresel tutarlılık sağlayacağı ifade edilmektedir (The Footnotes Analyst, 2020; Vatrenjak, 2019: 10). Denetim işlevinin ayrıca performans ölçütlerinin sunumunda işletmeleri daha dikkatli olmaya teşvik edeceği öngörülmektedir (Delhougne, 2018: 13).

\section{METODOLOJI}

Konunun literatürde sözü edilen önemine istinaden IFRS Vakfi ve IASB tarafindan yürütülen MPM çalışmasının ortaya çıkaracağı avantajlar ile dezavantajlarının neler olacağının ortaya konulması, bu araştırmanın temel amacıdır. Bu amaca yönelik cevapların bulunması ve geleceğe yönelik çıkarımların yapılabilmesi adına en uygun araştırma metodu seçilmiştir. Bu çerçevede çalışmada, araştırma amacı kapsamında elde edilmesi amaçlanan bilgilerin genellikle kitap, makale, rapor vb. belgelerden toplandığı ve çeşitli analiz 
tekniklerine göre birleştirildiği, sınıflandırıldığı ve yorumlandığı nitel yöntem kullanılmıştır. Nitel yöntemin uygulanması için araştırmanın amacına uygun olarak içerik analizi kullanımı tercih edilmiştir. İçerik analizinde ise teknik olarak değerlendirici analize başvurulmuştur. Değerlendirici analizde araştırma kapsamında incelenen tutum, mesaj ya da yorumlar belirli başlıklar altında analiz edilerek araştırma konusu hakkındaki görüşlerin lehte veya aleyhte olan yönü ve yoğunluğu belirlenir. Bu belirti ile araştırma konusu hakkında muhtelif değerlendirmeler yapılır (Arslanoğlu, 2016: 78; Bilgin, 2014: 11; İslamoğlu ve Alnıaçık, 2013: 203).

Gerçekleştirilecek nitel araştırmaya ve uygulanacak içerik analizine ilişkin veriler, IFRS Vakfı'nın internet sitesinde ${ }^{1}$ IASB'nin yürüttüğ̈̈ "Tartışma Taslağı ve Yorum Mektupları: Genel Sunum ve Açıklamalar (Temel Finansal Tablolar)" isimli çalışmasına ilişkin mesleki kurum ve kuruluşların, bankaların, ticari şirketlerin, danışmanlık şirketlerinin, derneklerin, vakıfların ve kişilerin yorum mektuplarından oluşmaktadır. Toplamda 216 adet olan mektuplardan bu çalışma kapsamına konu ile ilgili uluslararası düzeyde söz sahibi, temsil kabiliyeti ve geçerliliği olan 11 uluslararası kurum ve kuruluş, büyük dörtlü olarak nitelendirilen ve uluslararası düzeyde faaliyet yürüten 4 denetim şirketi ile Türkiye'de yetkili kurum olan KGK yorum mektupları araştırma kapsamına alınmıştır. İlgili kurum ve kuruluşların listesi Tablo 1'de sunulmaktadır.

Tablo 1. Araştırma Kapsamında Yer Alan Kurum ve Kuruluşlar

\begin{tabular}{ll}
\hline Uluslararası Kurum ve Kuruluşlar & Denetim Şirketleri \\
\hline Accountancy Europe (AE) & Deloitte \\
American Accounting Association (AAA) & Ernst \& Young (EY) \\
Asian-Oceanian Standard-Setters Group (AOSSG) & KPMG \\
Association of Chartered Certified Accountants (ACCA) & PwC \\
European Federation of Financial Analysts Societies (EFFAS) & \\
European Financial Reporting Advisory Group (EFRAG) & \\
European Securities and Markets Authority (ESMA) & \\
Institute of International Finance (IIF) & \\
Institute of Management Accountants (IMA) & Türkiye’deki Yetkili Kurum \\
\\
International Auditing and Assurance Standards Board (IAASB) \\
International Organization of Securities Commissions (IOSCO) & Kamu Gözetimi Kurumu (KGK) \\
\hline
\end{tabular}

IASB tarafından hazırlanıp kamuoyunun görüşüne sunulan ED/2019/7 kodlu “Taslak Metin - Genel Sunum ve Açıklamalar" içerisinde bu araştırmanın kapsamına alınan ve Tablo 1'de yer alan kuruluşların görüş bildirdiği "Yönetim Performans Ölçütleri” (MPM)

çalışmasına ilişkin bir kısım yer almaktadır. Taslak metin içerisinde yer alan MPM'ye ilişkin temel ilkeler aşağıdaki gibi özetlenebilir (IFRS Foundation, 2019a: 36c, 2019d):

Yönetim performans ölçütleri (MPM), aşağıdaki özelliklere sahip (kâr veya zarar tablosu ve diğer kapsamlı gelir tablolarındaki) gelir ve giderlerin ara toplamlarıdır:

Finansal tablolar dışındaki kamusal iletişimlerde kullanılır;

\footnotetext{
${ }^{1}$ https://www.ifrs.org/projects/work-plan/primary-financial-statements/comment-letters-projects/ed-primary-financial-statements/\#comment-letters
} 


\section{UFRS'de belirtilen tamamlayıc toplamlar veya ara toplamlardır ve}

İşletmenin finansal performansına ilişkin yönetim görüşünü kullanıcılara iletir.

UFRS tarafindan belirlenen brüt kar veya zarar ve benzeri ara toplamlar, amortisman ve itfa payından önceki faaliyet kar veya zararı, devam eden faaliyetlerden kaynaklanan kar veya zarar, vergi öncesi kar veya zarar gibi ara toplamlar yönetim performans ölçütleri olarak ifade edilmez.

Yönetim performans ölçütleri işletmenin finansal performansını finansal tablo kullanıcılarına gerçeğe uygun bir şekilde sunmalı, kullanıcıları yanıltmayacak şekilde açık ve anlaşılır bir şekilde tanımlanmalıdır.

IASB, işletmenin herhangi bir yönetim performans ölçütü hakkındaki bilgileri finansal tablolarda tek bir notta açıklamasını önermektedir. Bu not, yönetim performans ölçütlerinin işletmenin finansal performansının belirli bir yönü hakkında işletme yönetiminin görüşünü sağladığına ve diğer işletmeler tarafından sağlanan benzer ölçütler ile karşılaştırılabilir olmadığına dair ifadeleri de içerir.

Ayrıca işletme, ilgili not içerisinde her bir MPM için ölçütün neden kullanıldığı, nasıl hesaplandığ karşılaştırılabilir ara toplam veya toplam arasında bir mutabakatı, vergi etkisi ve kontrol gücü olmayan paylar üzerindeki etkisi gibi hususları da açıklamalıdır.

Bir işletmenin MPM hesaplamasını değiştirmesi (yalnızca yeni ölçütün daha yararlı bilgiler sağlaması durumunda değişime izin verilir), yeni bir MPM oluşturması veya daha önce açıklanan bir ölçütü finansal tablolarından çıkarması durumunda, finansal tablo kullanıcılarına değişiklik, ekleme, kaldırma ve bunların etkileri hakkında yeterli açıklama sunmalı, yapılan işlemlerin nedenlerini açıklamalı ve karşılaştırmayı sağlamak adına önceden sunulan MPM’leri yeniden düzenlemelidir.

Kurul'un yönetim performans ölçütleri için önerdiği tanım, gelir ve giderlerin alt toplamları ile sınırlıdır. Bu nedenle, diğer mali ölçütler (para birimine göre ayarlanmış gelir veya kullanılan sermaye getirisi gibi) ve mali olmayan ölçütler (müşteri elde tutma oranı gibi) MPM değildir.

IASB, paydaşlar ile iletişimde kullanılan finansal tablolar dışındaki araçlarda (faaliyet raporu, yatırımcı sunumları vb.) kullanılan performans ölçütlerinin finansal tablolarda açıklanan performans ölçütleri ile tutarlı olması gerektiğini belirtmektedir.

\section{BULGULAR}

Yönetim Performans Ölçütlerinin (MPM) UFRS'ye göre raporlama yapan işletmeler tarafından performans raporlamasının bir aracı olarak kullanılmasının ortaya çıkaracağı avantajların ve dezavantajların neler olabileceğine cevap arayan bu çalışma, kapsamına belirli niteliklere sahip 16 farklı kurum ve kuruluşu almıştır. Bunların IASB'ye gönderdiği yorum mektuplarının (toplam 323 sayfalık metin) nitel yöntem ve içerik analizi ile değerlendirilmesi sonucunda Tablo 2'de yer alan özet görünüm, araştırmanın temel bulgularını oluşturmaktadır. 
Tablo 2. MPM Taslağı Hakkında Kurum ve Kuruluşların Temel Görüşleri

\begin{tabular}{|c|c|c|c|c|c|c|c|}
\hline $\begin{array}{l}\text { Kurum/ } \\
\text { Kuruluş }\end{array}$ & MPM Çalışması & Kamusal İletişim & $\begin{array}{c}\text { Kapsam } \\
\text { (Gelir ve gider alt } \\
\text { toplamlart) }\end{array}$ & Denetim & Mutabakat & $\begin{array}{c}\text { Vergi ve Kontrol } \\
\text { Gücü Olmayan } \\
\text { Paylar } \\
\end{array}$ & UFRS 8 ile İlişki \\
\hline $\mathrm{AE}$ & Desteklenmektedir & $\begin{array}{c}\text { Yeniden } \\
\text { değerlendirilmelidir }\end{array}$ & Genişletilmelidir & - & - & - & Açıç̧a belirtilmelidir \\
\hline AAA & Desteklenmektedir & - & $\begin{array}{l}\text { Genişletme konusu } \\
\text { gözden geçirilmelidir }\end{array}$ & $\begin{array}{l}\text { Denetim kapsamına } \\
\text { alınması önemli } \\
\text { görülmektedir }\end{array}$ & $\begin{array}{l}\text { Belirli bir formata göre } \\
\text { yapılması talep } \\
\text { edilmektedir }\end{array}$ & Faydalı görülmektedir & - \\
\hline AOSSG & $\begin{array}{c}\text { Üye ülkelerin çoğu } \\
\text { desteklemekte iken bazı } \\
\text { üyeler } \\
\text { desteklememektedir }\end{array}$ & $\begin{array}{l}\text { Netlesstirilmesi } \\
\text { gerekmektedir }\end{array}$ & $\begin{array}{l}\text { Netleștirilmeli ya da } \\
\text { genişletilmelidir }\end{array}$ & 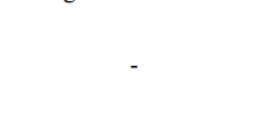 & 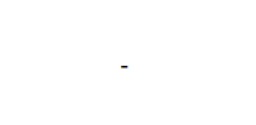 & - & - \\
\hline ACCA & $\begin{array}{c}\text { Şartlı olarak } \\
\text { desteklenmektedir }\end{array}$ & - & $\begin{array}{l}\text { Diğer ölçütlerin neden } \\
\text { olmadığı açıllanmalıdır }\end{array}$ & $\begin{array}{l}\text { Yeni sorumluluklar } \\
\text { getireceği } \\
\text { düşünülmektedir }\end{array}$ & - & - & $\begin{array}{l}\text { Eksiksiz bir şekilde } \\
\text { açıklanmalıdır }\end{array}$ \\
\hline EFFAS & Desteklenmektedir & - & - & $\begin{array}{l}\text { Kullanıcilara güven tesis } \\
\text { etmektedir }\end{array}$ & Fayda sağlamaktadır & - & - \\
\hline EFRAG & Desteklenmektedir & Kapsamı daraltılmalıdır & Genişletilmelidir & - & - & $\begin{array}{l}\text { Maliyet ve faydası } \\
\text { gözden geçirilmelidir }\end{array}$ & $\begin{array}{l}\text { Net bir şekilde ortaya } \\
\text { konmalıdır }\end{array}$ \\
\hline ESMA & Desteklenmektedir & $\begin{array}{l}\text { Netleştirilmeli ve } \\
\text { örneklendirilmelidir }\end{array}$ & $\begin{array}{l}\text { Genişletme konusu } \\
\text { gözden geçirilmelidir }\end{array}$ & - & - & $\begin{array}{l}\text { Maliyet ve faydası } \\
\text { gözden geçirilmelidir }\end{array}$ & - \\
\hline IAASB & Desteklenmektedir & $\begin{array}{c}\text { Çok geniş } \\
\text { yorumlanabilme endişesi } \\
\text { vardır }\end{array}$ & Genişletilmelidir & $\begin{array}{l}\text { Kamusal iletişim } \\
\text { tanımından dolayı } \\
\text { sorunlar yaşanabilir }\end{array}$ & - & - & $\begin{array}{l}\text { Net bir şekilde } \\
\text { açıklanması } \\
\text { gerekmektedir }\end{array}$ \\
\hline IIF & Desteklenmemektedir & $\begin{array}{l}\text { Açıklığa kavuşturulmalı } \\
\text { ve sinırlandırılmalıdır }\end{array}$ & - & - & - & $\begin{array}{l}\text { Ağır maliyetler } \\
\text { oluş̧uracaktır }\end{array}$ & - \\
\hline IMA & Desteklenmemektedir & Tanım çok geniştir & - & Yapılması zordur & - & - & - \\
\hline IOSCO & Desteklenmektedir & Tanım çok geniştir & $\begin{array}{l}\text { Sadece gelir ve giderler } \\
\text { ile sinırlandırılması } \\
\text { sorgulanmaktadır }\end{array}$ & - & Faydalı görülmektedir & $\begin{array}{l}\text { Maliyetleri ve yükü } \\
\text { endişe konusudur }\end{array}$ & - \\
\hline Deloitte & Desteklenmemektedir & $\begin{array}{c}\text { Yeniden } \\
\text { değerlendirilmelidir }\end{array}$ & - & $\begin{array}{l}\text { Beklenti boşluğunu } \\
\text { artırma riski vardır }\end{array}$ & - & - & - \\
\hline EY & Desteklenmektedir & - & $\begin{array}{c}\text { Yeniden } \\
\text { değerlendirilmelidir }\end{array}$ & $\begin{array}{l}\text { Gözden geçirilmeli ve } \\
\text { netleştirilmelidir }\end{array}$ & - & - & $\begin{array}{l}\text { Net bir şekilde ortaya } \\
\text { konmalıdır }\end{array}$ \\
\hline KPMG & Desteklenmektedir & $\begin{array}{l}\text { Tanım çok geniștir, } \\
\text { daraltılmalıdır }\end{array}$ & Genişletilmelidir & - & - & - & - \\
\hline $\mathrm{PwC}$ & Desteklenmektedir & $\begin{array}{l}\text { Netleştirilmeli ya da } \\
\text { sinırlandırılmalıdır }\end{array}$ & Genişletilmelidir & - & - & - & - \\
\hline KGK & Desteklenmektedir & - & Genişletilmelidir & Zor ve maliyetli olabilir & - & $\begin{array}{l}\text { Zorlayııı olacağı } \\
\text { düşünülmektedir }\end{array}$ & - \\
\hline
\end{tabular}


Tablo 2'den hareketle IASB'nin MPM çalışması ile ilgili kurumların temel görüşlerine ait temel bulgular aşağıdaki gibi özetlenebilir:

$>\quad$ Çalışma, araştırma kapsamındakilerin çoğunluğu (\%75'i) tarafindan desteklenmektedir. Söz konusu 16 kurumdan 11'i desteklemekte, 1'i şartlı desteklemekte, 3'ü desteklememekte, 1'inde ise üye ülkelerin bazıları desteklemekte bazıları da desteklememektedir.

Destekleyenlerin temel görüşü, MPM'lerin hem işletmelere hem de işletme ile ilgili karar vericilere fayda sağlayacağı, kullanımı giderek artan UFRS harici ölçütlere şeffaflık, tutarlılık ve güvenilirlik getireceğidir. Ayrıca MPM'lerin tek bir notta yer almasının zorunlu kılınmasının finansal tabloların yararlılığında bir artış anlamına geldiği ve bilgiye erişimin daha kolay olacağı (istenilen bilgiye ulaşmak adına finansal tablolar içinde geçirilen zamanın azalacağı) ifade edilmektedir. $\mathrm{Bu}$ nedenle IASB'nin ilgili çalışması önemli görülmektedir.

> Desteklemeyenlerin temel görüşü, MPM'lerin UFRS’lerin temel çerçevesine aykırı olduğu, denetim konusunda riskler oluşturacağı, halihazırda ESMA APM Kılavuzu gibi benzer düzenlemeler olduğu için karmaşıklığa yol açabileceği yönündedir. Ayrıca MPM'lerin sağlayacağı faydaların finansal tabloların hazırlanması ve denetiminde ortaya çıkan ek maliyetlerden daha fazla olacağından emin olmayan görüşler de mevcuttur. Diğer taraftan yönetim performans ölçütlerine ilişkin gözetimin, IASB'nin değil, menkul kıymet düzenleyicilerinin sorumluluğunda olduğu ve GKGMİ harici ölçütlerin mali tablolara ait olmadı̆̆ 1 da ifade edilmektedir.

Desteklemeyenler endişe duydukları temel hususları belirtirken diğer taraftan destekleyenler de çalışmaya ilişkin sorularını, endişelerini ve taleplerini ifade etmektedir. Söz konusu hususların yoğunlaştığı temel başlıklara ilişkin araştırma kapsamındakilerin ifade ettiği avantajlar ve dezavantajlar şunlardır:

$\checkmark \quad$ Kamusal iletişim (ölçütlerin hangi araçlar vasıtası ile sunulacağ̀): IASB'nin MPM çalışmasında yer alan ve MPM'lerin kullanılacağı alanları temsil eden bu ifade taslağı hem destekleyen hem de desteklemeyenler tarafından en çok eleştirilen konulardan biridir. Görüş bildirenlerin tümü ölçütlerin kullanılacağı alanların bu ifade ile çok geniş tutulduğunu (sosyal medya gönderileri, röportajlarda yapılan yorumlar, podcastler, telekonferanslar vb.) ve belirsiz olduğunu, bu nedenle de netleştirilmesi, sınırlandırılması ya da daraltılması gerektiğini ifade etmektedir. Bu durumun aynı zamanda denetim ve denetçiler için bir zorluk teşkil edeceği belirtilmektedir. Kuruluşlar bu ifadenin gözden geçirmesini talep ya da tavsiye etmektedir.

$\checkmark \quad$ Kapsam (ölçütlerin sadece kâr veya zarar ve diğer kapsamlı gelir tablosunda yer alan gelir ve giderlerin alt toplamlarından oluşmast): Halihazırda kullanılan UFRS harici ölçütlerin kapsamı bu şekilde sınırlandırılmazken IASB'nin böyle bir yaklaşım benimsemesi anlaşılabilir bulunmakla birlikte eleştirilmektedir. Bu durumun MPM'lerden beklenen faydayı azaltacağı düşünülmektedir. Bunun nedeni olarak APM'lere ilişkin yakın tarihli araştırmalarda, kâr veya zarar dışındaki ölçütlerin (örneğin; net borç, öz sermaye getirisi, serbest nakit akışı vb.) kullanıcılar tarafından yaygın olarak kullanılmasıdır. Dolayısıyla kuruluşlar ölçütlerin kapsamının genişletilmesi, netleştirilmesi ve diğer unsurların (finansal 
durum, nakit akış, vb.) kapsama dahil edilmesi ya da neden dahil edilmediğinin açıklanması talebinde bulunmaktadır. Diğer taraftan, UFRS harici performans ölçütleri terminolojisinin oldukça geniş olmasından dolayı IASB'nin oluşturduğu düzenlemenin "Finansal Performans Beyanı ile ilgili MPM" olarak değiştirilmesi önerilmektedir.

$\checkmark \quad$ Denetim: Görüş bildirenler, MPM'lerin UFRS'ye göre hazırlanan raporlar içerisinde yer alması nedeni ile bu ölçütlerin denetim kapsamında olacağını ifade etmektedir. Ayrıca UFRS harici ölçütlere ilişkin yapılan en büyük eleştirilerden biri olan denetim eksikliğinin bu yolla giderileceği yorumlaması yapılmaktadır. Ancak bu denetimin yapılmasının MPM'ler hesaplanırken yapılacak düzeltme işlemlerinde UFRS'lere uymayan muhasebe politikalarının kullanılmasından dolayı zor ve maliyetli olabileceği, denetim komiteleri ve denetçiler için yeni sorumluluklar ortaya çıkaracağı ve beklenti boşluğunu artırabileceği ifade edilmektedir.

$\checkmark \quad$ Mutabakat: Araştırma kapsamındaki kurum ve kuruluşlardan sadece üçü mutabakat konusunda değerlendirmede bulunmuştur. Bunlardan ikisi MPM'lerin en yakın UFRS rakamları ile mutabakatının yapılmasını faydalı bulmaktadır. Bir diğeri ise yapılacak mutabakatların karmaşıklığa yol açmaması adına IASB tarafından belirlenecek belirli bir formata göre yapılmasını tavsiye etmektedir.

$\checkmark \quad$ Vergi ve kontrol gücü olmayan payların etkisi: Yapılacak mutabakatların her bir kalemi için vergi ve kontrol gücü olmayan paylarının etkisinin açıklanmasının fayda sağlayacağı düşünülmektedir. Ancak bu faydanın ilgili açıklamaları oluşturmanın maliyetinden daha fazla olmayacağı da ifade edilmektedir. Bu sebeple söz konusu unsurların her bir mutabakat kalemi için açıklanmasının tekrar gözden geçirilmesi talep ve tavsiye edilmektedir.

$\checkmark \quad$ UFRS 8 ile ilişki: İşletme yönetimleri, halihazırda UFRS 8 Faaliyet Bölümleri standardını kullanarak faaliyetlerine ilişkin bölümlerin performansını raporlamaktadır. MPM'lerin de işletme yönetiminin performansa dair görüşünü yansıtmasından dolayı her iki düzenlemenin arasındaki ilişkinin net bir şekilde ortaya konması görüşü yorum yapan kurum ve kuruluşların ortak talebidir.

Yönetim performans ölçütlerine ilişkin araştırma sonucunda ilgili kurumlar tarafından yukarıda yer alan temel başlıklar dışında aşağıda yer alan hususlar da belirtilmektedir.

$\checkmark \quad$ İşletmeler, şeffaflık sağlamak adına performans ölçütlerinin amacını ve sınırlamalarını açıkça sunmalıdır. Ayrıca, işletmeler yönetim performans ölçütünün işletmeye özgü olduğunu, finansal performansa ilişkin bir yönetim görüşü sağladığını ve diğer işletmelerce kullanılan ölçütlerle karşılaştırılabilir olmadığını belirtmelidir. Diğer taraftan MPM'lere UFRS dahilindeki ölçütlerden daha fazla önem verilmemesi gerektiği de ifade edilmektedir.

$\checkmark \quad$ MPM'ler ile ilgili olarak üzerinde durulan hususlardan biri de UFRS setinde halihazırda izin verilmeyen olağandışı gelir ve giderlerin sunumuna ilişkindir. İşletmeler, MPM'leri oluştururken genellikle olağandışı gelir ve giderlere (yinelenmeyen, seyrek, sıra dışı, bir defalık gibi ifadeler de kullanılmaktadır) göre düzeltme yapmaktadır. Bu nedenle geri 
bildirimde bulunan taraflar MPM'lerin olağandışı gelir-gider kalemleriyle olan bağlantısına ilişkin açıklama gerekliliklerinin daha net bir şekilde ortaya konulmasını talep edilmektedir.

$\checkmark \quad$ Tartışılan konulardan biri faiz, vergi ve amortisman öncesi kâr (EBITDAFAVÖK) ölçütünün MPM sayılıp sayılmayacağı konusundadır. FAVÖK, çeşitli analizler için yararlı bir başlangıç noktası olmasının dışında, kullanıcıların FAVÖK'ün neyi temsil ettiği konusunda bir fikir birliği yoktur ve hesaplaması çeşitlidir. Sonuç olarak, FAVÖK ölçütü yönetim performans ölçütleri tanımını karşılayabilmektedir. Bu nedenle de bir MPM olarak değerlendirilmelidir.

$\checkmark \quad$ İşletmelerin MPM'leri zamanlama olarak ne zaman kamuya açık olarak sunacakları konusunda netleştirme yapılması gerektiği düşünülmektedir. Örneğin, bir işletmenin cari yıl için finansal tablolarının yayınlanmasının ardından yapılacak yatırımcı sunumuna bir MPM dahil etmeyi planladığında, finansal tablo notlarına yeni bir MPM ekleyebilir mi? Bu ve benzeri hususların netleştirilmesi gerekmektedir.

$\checkmark \quad$ MPM'lerin diğer benzer düzenlemeler ile (ESMA-Guidelines on Alternative Performance Measures, IOSCO-Statement on Non-GAAP Financial Measures, SEC-NonGAAP Financial Measures) ile tutarlı olmasının fayda sağlayacağı ifade edilmektedir. Düzenlemeler arasında ortaya çıkabilecek olası çatışmalar konusunda da IASB'nin gerekli açıklamaları şeffaf ve net bir şekilde ortaya koyması tavsiye edilmektedir.

\section{SONUÇ}

IFRS Vakfi, 2020 yıllık raporunda finansal tablolardaki açıklamaların etkinliğini iyileştirmek için halihazırda devam etmekte olan "Finansal Raporlamada Daha İyi İletişim" ve "Temel Finansal Tablolar" gibi benzeri projeler üzerindeki çalışmaların devam ettiğini belirtmektedir. Ayrıca bu projelerin sonuçlandırılması ile finansal bilgilerin yatırımcılara iletilmesinde önemli iyileştirmelerin sağlanacağı vurgulanmaktadır. Diğer taraftan IASB başkanı Hans Hoogervorst'ın 2020 yılı içerisinde yaptığı değerlendirmelerde yukarıda sözü edilen projeler çerçevesinde finansal tablolara UFRS harici ölçütlerin ekleneceğini ifade ederek şu an taslak aşamasında olan MPM çalışmasına kurul tarafından son halinin verileceği ve uygulamaya konulacağı konusundaki kararlılığı belirtmiştir. Covid-19 pandemisi doğal olarak yaşanan bu sürecin ötelenmesine neden olmuştur.

IASB'nin performans ölçütleri ile ilgili yürüttüğü çalışmanın uygulamada sağlayacağı avantaj ve dezavantajların tespit edilmesini amaçlayan bu araştırma sonucunda; araştırma kapsamındaki kuruluşların çoğu tarafından MPM taslağının finansal tablo kullanıcılarına ve işletmelere genel olarak fayda sağlayacağı ve bu nedenle de IASB'nin çalışmasının desteklendiği görülmektedir. Ancak bu destek ile birlikte taslağı hem destekleyenler hem de desteklemeyenlerin belirttiği bazı endişeler söz konusudur. Bunlar; taslakta kullanılan kamusal iletişim ifadesi, MPM'nin oluşturulmasındaki kapsam (sadece kâr veya zarar ve diğer kapsamlı gelir tablosundaki gelir ve gider alt toplamları ile sınırlandırılması), denetim, mutabakat, vergi ve kontrol gücü olmayan paylar üzerindeki etki ile UFRS 8 Faaliyet Bölümler Standardı ile ilişkiye dairdir. Bu hususlar hakkında görüş bildirenler tarafından netleştirme, şeffaflık, açıklık ve örneklendirme gibi taleplerde bulunulmaktadır. Bu taleplerin dikkate alınması ile MPM'lerin oluşturabileceği bazı dezavantajlarının ortadan kalkabileceği veya sınırlandırılabileceği ya da avantajlarının artırılabileceği ifade edilmektedir. 
Araştırmanın ortaya çıkmasını sağlayan "Geçerli finansal raporlama çerçevesi (GKGMİ, UMS/UFRS, US-GAAP, vb.) haricinde oluşturulan performans ölçütleri, uluslararası standartlara sahip bir kılavuz çerçevesinde mi hazırlanmalıdır?" sorusuna istinaden yapılan çalışma sonucunda "Evet" cevabının verilmesi, gelinen noktada bir istekten ziyade bir zorunluluk teşkil etmektedir. $\mathrm{Bu}$ zorunluluk hem işletmeler hem de işletme paydaşlarınca giderek artan bir oranda talep edilmektedir. Ancak bu zorunluluk dogrultusunda ortaya konacak olan uluslararası bir rehberin ya da kılavuzun araştırmada da belirtilen tüm endişeleri açık bir şekilde gidermesi, uluslararası bir mutabakatın sağlanması ve Avrupa Menkul Kıymetler ve Piyasalar Otoritesinin Kılavuzu gibi diğer benzeri yasal düzenlemeler ile yaşanabilecek karmaşıklıklara karşı çözümler üretilmesi gerekmektedir.

Son olarak Türkiye'deki UFRS harici ölçütlere ilişkin şu değerlendirme yapılabilir: Uluslararası düzeyde olduğu gibi Türkiye'deki çoğu şirket de bu ölçütleri kullanmaktadır. Ancak Türkiye'de söz konusu ölçütlere ilişkin herhangi bir düzenleme (örneğin, ESMA APM K1lavuzu) bulunmamakta ya da önerilmemektedir. KGK'nın IASB'nin MPM taslağına gönderdiği yorum mektubu, Türkiye'de bu ölçütler ile ilgili yetkili kurumlar tarafindan yapılan ilk ve tek resmi açıklama olarak gösterilebilir. Bu doğrultuda yetkili kurumların (KGK, SPK, BDDK vb.) konu ile ilgili daha çok açıklama ya da yönlendirme yapmalarının Türkiye'deki şirketler ve finansal tablo kullanıcıları açısından fayda sağlayacağı düşünülmektedir.

\section{KAYNAKLAR}

Accountancy Europe - AE, (2020), "Exposure Draft - General Presentation And Disclosures (Primary Financial Statements) Accountancy Europe comment letter", http://eifrs.ifrs.org/eifrs/comment_letters//554/554_26682_JonaBashaAccountancyEur ope_0_200930PFSED_ACEresponse.pdf(Erişim tarihi: 03 Ocak 2021).

Akinwale, Aishat - Donkersley, Kathryn, (2018), Staff paper - better communication in financial reporting projects, IASB Agenda Ref 11A (project: disclosure initiative: Principles of disclosure).

Alibhai, Salim - Bakker, Erwin - Balasubramanian, T V - Bharadva, Kunal - Chaudhry, Asif Coetsee, Danie - ... Merwe, Minette van der, (2019), Wiley 2019 interpretation and application of IFRS standards, John Wiley \& Sons Ltd., Cornwall.

American Accounting Association - AAA, (2020), "Response to IFRS Exposure Draft ED/2019/7 general presentation and disclosures", http://eifrs.ifrs.org/eifrs/comment_letters//554/554_26685_StephenStubbenAmericanA ccountingAssociationAAA_0_IASBEDPresentationFINAL.pdf (Erişim tarihi: 03 Ocak 2021).

Arslanoğlu, İbrahim, (2016), Bilimsel Yöntem Ve Araştırma Teknikleri, Gazi Kitabevi, Ankara.

Asian-Oceanian Standard-Setters Group - AOSSG, (2020), "Comment Letter by the AsianOceanian Standard-Setters Group (AOSSG) on the International Accounting Standards Board's ('the IASB's') exposure draft ('the ED') general presentation and disclosures 
(ED/2019/7)",

http://eifrs.ifrs.org/eifrs/comment_letters//554/554_26828_DrShiwajiBhikajiZawareAs ianOceanianStandardSettersGroupAOSSG_0_200929_commentletterontheIASBED_g eneralpresentationanddisclosures.pdf (Erişim tarihi: 03 Ocak 2021).

Association of Chartered Certified Accountants - ACCA, (2020), "General Presentation And Disclosures - Exposure Draft Issued For Comment by the International Accounting Standards Board - Comments From ACCA", http://eifrs.ifrs.org/eifrs/comment_letters//554/554_26875_RICHARDMARTINAssoci ationofCharteredCertifiedAccountantsACCA_0_generalpresentationanddisclosuresRes p.pdf (Erişim tarihi: 03 Ocak 2021).

Bamber, Linda Smith - Jiang, John (Xuefeng) - Petroni, Kathy R. - Wang, Isabel Yanyan, (2010), Comprehensive Income: Who's Afraid of Performance Reporting? The Accounting Review, 85(1), pp. 97-126, https://doi.org/10.2308/accr.2010.85.1.97

Bilgin, Nuri, (2014), Sosyal Bilimlerde İçerik Analizi: Teknikler Ve Örnek Çalışmalar, Siyasal Kitabevi, Ankara.

Bogle, Kevin, (2017), Non-GAAP Financial Measures are Thriving, https://advisory.kpmg.us/articles/2017/non-gaap-financial-measures-are-thriving.html (Erişim tarihi: 02 Ocak 2021).

Bölükbaş, Tarık, (2019), Finansal Raporlama Standartları Uygulamalarında Küresel Gelişme Ve Fırsatlar: Yeni Raporlama Dili İçinde XX. Türkiye Muhasebe Kongresi Cilt 2: Dijitalleşme Sürecinde Değişen İş Hayatı ve Muhasebe Mesleğinin Yeniden Yapılanması - “Yerel/Küresel Meseleler, Küresel/Yerel Çözümler” (ss. 1351-1359). İstanbul: TÜRMOB Yayınları.

Bouvier, Stephen, (2018), "Reporting Metrics: Management Knows Best", https://www.ipe.com/reporting-metrics-management-knows-best/10022964.article (Erişim tarihi: 02 Ocak 2021).

CA ANZ, (2020), "The Changing Face of the Profit or Loss Statement", News \& Analysis, https://www.charteredaccountantsanz.com/news-and-analysis/news/the-changing-faceof-the-profit-or-loss-statement (Erişim tarihi: 02 Ocak 2021).

Clinch, Greg - Tarca, Ann - Wee, Marwin, (2019), Exploring Comparability in Disclosure of Non-IFRS Performance Measures, SSRN Electronic Journal, https://doi.org/10.2139/ssrn.3343965

Delhougne, Anne-Sophie, (2018), To What Extent Could Alternative Performance Measures be Considered As Sector-based?

Deller, Adam, (2018), "Mixed Feelings on the IASB's Disclosure And Primary Statements Projects", Https://Www.Accaglobal.Com/Gb/En/Member/Discover/CpdArticles/Corporate-Reporting/deller-may18cpd.html (Erişim tarihi: 02 Ocak 2021).

Deller, Adam, (2019), "Alternative Performance Measures Need To Stay in their Proper 
Place", ACCA CPD technical article, https://www.accaglobal.com/gb/en/member/discover/cpd-articles/corporatereporting/dellercpd-apr19.html (Erişim tarihi: 05 Ocak 2021).

Deller, Adam, (2020), "Financial Statement Change", https://www.accaglobal.com/ca/en/member/discover/cpd-articles/corporatereporting/dellercpd-feb20.html (Erişim tarihi: 03 Ocak 2021).

Deloitte, (2017), IASB Publishes A Discussion Paper On Principles Of Disclosures.

Deloitte Touche Tohmatsu Limited, (2020), "Deloitte Touche Tohmatsu Limited is pleased to respond to the International Accounting Standards Board's ('the IASB's') exposure draft general presentation and disclosures", http://eifrs.ifrs.org/eifrs/comment_letters//554/554_26889_MARTINEPELLETIERDe loitteToucheTohmatsuLimitedDTTL_0_DTTLcommentletter_ED20197.pdf (Erişim tarihi: 03 Ocak 2021).

EFRAG, (2020), Primary Financial Statements Summary Report.

EFRAG Secretariat: PFS team, (2020), Primary Financial Statements Cover Note.

Elisabetta, Barone - Claudio, Teodori, (2020), The Standard Setters' Approach To The NonGAAP Measures İçinde Nicola Moscariello - Michele Pizzo (Ed.), Reporting NonGAAP financial Measures: A Theoretical and Empirical Analysis in Europe (pp. 94116). Cambridge Scholars Publishing, Newcastle.

Ernst \& Young, (2018), Applying IFRS: Alternative Performance Measures, London.

Ernst \& Young, (2020a), Applying IFRS - Impact of Coronavirus On Alternative Performance Measures And Disclosures.

Ernst \& Young, (2020b), Financing and Investing entities: Proposed Changes To Primary Financial Statements, IFRS Developments.

Ernst \& Young Global Limited, (2020), "Invitation to comment - Exposure draft ED/2019/7/general presentation and disclosures." http://eifrs.ifrs.org/eifrs/comment_letters//554/554_26790_ELIZABETHHENRYEY_ 0_CLED2019_7GeneralPresentationandDisclosure.pdf (Erişim tarihi: 03 Ocak 2021).

European Federation of Financial Analysts Societies - EFFAS, (2020), "Comments on IFRS Standards ED/2019/7 on general presentation and disclosures", http://eifrs.ifrs.org/eifrs/comment_letters//554/554_26794_RaquelZaragozaTheEurope anFederationofFinancialAnalystsSocietiesEFFAS_0_EFFASCommentsonIFRSStanda rdsED20197onGeneralPresentationandDisclosuresSeptember2020.pdf (Erişim tarihi: 03 Ocak 2021).

European Financial Reporting Advisory Group - EFRAG, (2020), "EFRAG comment letter re: IASB ED/2019/7 general presentation and disclosures", http://eifrs.ifrs.org/eifrs/comment_letters//554/554_27067_FilipeAlvesEuropeanFinan 
cialReportingAdvisoryGroupEFRAG_0_EFRAG.pdf (Erişim tarihi: 03 Ocak 2021).

European Securities and Markets Authority - ESMA, (2020), "Ref: IASB's exposure draft general presentation and disclosures", http://eifrs.ifrs.org/eifrs/comment_letters//554/554_26743_AnnaSciortinoESMA_0_E SMA3261397CommentLettertoIASBonEDPFS.pdf (Erişim tarihi: 03 Ocak 2021).

FIN-FSA, (2019), IASB Intends to Clarify Income Statement Presentation And To Introduce Management Performance Measures in The Financial Statements, Market newsletter.

Fisher, Michelle, (2018), Staff paper - Requirements For Management Performance Measures (MPMs), IASB agenda ref 21A (project: Primary financial statements).

Flores, Françoise, (2019), IASB update, Paris.

Gökten, Pınar Okan, (2019), Uluslararası Muhasebe Standartları Kurulu'nun performans Raporlamasına Bakış Açısı: 1989'dan 2018'e Ne Değişti? Muhasebe ve Vergi Uygulamalar1 Dergisi, 12(2), ss. 475-496, https://doi.org/10.29067/muvu.485653

Grant Thornton, (2018), IFRS news.

Grant Thornton, (2019), New Developments Summary - Highlights of the 2019 AICPA conference on current SEC and PCAOB developments.

Grant Thornton, (2020), IASB Proposes Major Changes to the Primary Statements And Notes, IFRS Alert.

Hood, Daniel, (2019), "IASB Proposes Major Revamp to Financial Reporting", https://www.accountingtoday.com/news/iasb-proposes-major-revamp-to-financialreporting (Erişim tarihi: 02 Ocak 2021).

Hoogervorst, Hans, (2015), Mind the Gap (between non-GAAP and GAAP) (IASB speech) içinde Korean Accounting Review International Symposium (pp. 1-7), Seoul.

Hoogervorst, Hans, (2016a), Latest Developments And Future Focus (IASB speech), Joint IFRS Foundation, PAFA and ICPAK Conference (pp. 1-7), Nairobi.

Hoogervorst, Hans, (2016b), Performance Reporting and the Pitfalls Of Non-GAAP Metrics, Annual Conference of the European Accounting Association, Maastricht.

Hoogervorst, Hans, (2019), The Primary Financial Statements Project - A Game Changer in Financial Reporting? (IASB Speech), International Seminar On IFRS And NIF trends and perspectives of the World Accounting Standards (pp. 1-7), Mexico City.

Hughes, John, (2020), "General Presentation And Disclosures - New Subtitles, New Game!" https://disclosurehub.org/2020/02/10/general-presentation-and-disclosures-newsubtitles-new-game (Erişim tarihi: 02 Ocak 2021).

ICAEW, (2020), "General Presentation And Disclosures: ICAEW's point of view", 
https://www.icaew.com/insights/viewpoints-on-the-news/2020/dec-2020/generalpresentation-and-disclosures-icaews-point-of-view (Erişim tarihi: 03 Ocak 2021).

IFRS Foundation, (2017), Better Communication İn Financial Reporting: Making Disclosures More Meaningful, London.

IFRS Foundation, (2019a), "Basis For Conclusions On Exposure Draft (ED/2019/7) General Presentation And Disclosures", https://cdn.ifrs.org/-/media/project/primary-financialstatements/exposure-draft/ed-basis-for-conclusions-general-presentationdisclosures.pdf (Erişim tarihi: 03 Ocak 2021).

IFRS Foundation, (2019b), "Exposure draft (ED/2019/7) general Presentation And Disclosures", $\quad$ https://cdn.ifrs.org/-/media/project/primary-financialstatements/exposure-draft/ed-general-presentation-disclosures.pdf (Erişim tarihi: 03 Ocak 2021).

IFRS Foundation, (2019c), "Primary Financial Statements", https://www.ifrs.org/projects/work-plan/primary-financial-statements/\#about (Erişim tarihi: 28 Aralık 2020).

Institute of Directors, (2020), "Game-changer Proposal For How İnformation İs Presented in Financial Reports", https://www.iod.org.nz/resources-and-insights/news-andarticles/game-changer-proposal-financial-reports (Erişim tarihi: 04 Ocak 2021).

Institute of International Finance - IIF, (2020), "RE: Exposure draft ED/2019/7 general presentation and disclosures", http://eifrs.ifrs.org/eifrs/comment_letters//554/554_26776_StefanGringelInstituteofInt ernationalFinanceIIF_0_CL61IIF.pdf (Erişim tarihi: 03 Ocak 2021).

Institute of Management Accountants - IMA, (2020), "Re: IFRS Standards Exposure Draft ED/2019/7 general presentation and disclosures", http://eifrs.ifrs.org/eifrs/comment_letters//554/554_26661_NancySchroederIMAFRC_ 0_FRCCommentLetterIASBPresentationDisclosure.pdf (Erişim tarihi: 03 Ocak 2021).

International Auditing and Assurance Standards Board - IAASB, (2020), "Re: Comments on IASB's exposure draft (ED), general presentation and disclosures", http://eifrs.ifrs.org/eifrs/comment_letters//554/554_26951_BEVERLEYBAHLMANN InternationalAuditingandAssuranceStandardsBoardIAASB_0_IAASBCommentLettert oIASBonGeneralPDEDFinal.pdf (Erişim tarihi: 03 Ocak 2021).

International Organization of Securities Commissions - IOSCO, (2020), "RE: General presentation and disclosures", http://eifrs.ifrs.org/eifrs/comment_letters//554/554_26845_AccountingJFSAInternatio nalOrganizationofSecuritiesCommissionsIOSCO_0_IOSCOC1letter_GeneralPresentat ionandDisclosures.pdf (Erişim tarihi: 03 Ocak 2021).

İslamoğlu, Ahmet Hamdi - Alnıaçık, Ümit, (2013), Sosyal Bilimlerde Araştırma Yöntemleri, Beta Basım Yayım Dağıtım, İstanbul. 
Jana, Stephanie - McMeeking, Kevin, (2020), Alternative Performance Measures: Determinants Of Disclosure Quality - Evidence From Germany, Accounting in Europe, pp. 1-41, https://doi.org/10.1080/17449480.2020.1829655

Kadlecová, Jitka, (2020), "IASB Proposes A New Standard On General Presentation And Disclosures in Financial Statements", https://www.dreport.cz/en/blog/iasb-proposes-anew-standard-on-general-presentation-and-disclosures-in-financial-statements (Erişim tarihi: 06 Ocak 2021).

Kamu Gözetimi Kurumu - KGK, (2020), "Comment Letter By The Public Oversight Accounting And Auditing Standards Authority On The Exposure Draft General Presentation And Disclosure", http://eifrs.ifrs.org/eifrs/comment_letters//554/554_26798_ALIUTKUDOGANOGLU THEPUBLICOVERSIGHTACCOUNTINGANDAUDITINGSTANDARDSAUTHO RITY_0_THEPOACOMMENTLETTERONEXPOSUREDRAFT.pdf (Erişim tarihi: 03 Ocak 2021).

Karmańska, Anna, (2014), "The Imperative Of Sustainable Growth And Reporting Integration, Three Eras in The Corporate Reporting Development", Copernican Journal of Finance \& Accounting, 3(1), pp. 73-82, https://doi.org/10.12775/CJFA.2014.006

Kegalj, Gabriela, (2020), Re-shaping Presentation in Financial Statements, KPMG IFRG Limited - IFRS News.

Knight, Scott, (2020), "Profit or Loss Statements May Be Changing", https://www.bdo.co.uk/en-gb/insights/audit-and-assurance/ifrs-us-gaap-and-

international-gaap/profit-or-loss-statements-may-be-changing (Erişim tarihi: 02 Ocak 2021).

KPMG IFRG Limited, (2020), "Comment letter on exposure draft ED/2019/7 General Presentation And Disclosures", http://eifrs.ifrs.org/eifrs/comment_letters//554/554_26816_rumehussainKPMGIFRGLi mited_0_KPMGcommentletteronED201907GeneralPresentationandDisclosures.pdf (Erişim tarihi: 03 Ocak 2021).

Lange, Nicolette - Voilo, Jelena - Feygina, Yulia, (2020), Staff Paper - Management Measures And Indicators, IASB agenda ref 15D (project: management commentary).

Liikanen, Erkki, (2019), IFRS Foundation, Helsinki.

Maurer, Mark, (2019), "IASB Proposes Rule Requiring More Details On Profit, Income", https://www.wsj.com/articles/iasb-proposes-rule-requiring-more-details-on-profitincome-11576576800 (Erişim tarihi: 04 Ocak 2021).

Meteil-Dutartre, Patricia, (2020), "New financial statements, comments on IFRS project", https://blogs.sap.com/2020/07/17/new-financial-statements-comments-on-ifrs-project (Erişim tarihi: 04 Ocak 2021). 
MIA, (2019), "How to Apply And İmprove Reporting Of Alternative Performance Measures in Corporate Reporting", https://member.mia.org.my/mia/mia_uat/mia/flyer/30891/Flyer (Erişim tarihi: 06 Ocak 2021).

Mısırlıoğlu, İsmail Ufuk, (2006), İşletmelerde Finansal Performans Raporlanması, Mali Çözüm Dergisi, (75), ss. 23-34.

Morgan, Robert, (2020), "Mind the non-GAAP", https://cruf.com/mind-the-non-gaap (Erişim tarihi: 03 Ocak 2021).

Muc, Marek, (2020), "Operating segments (IFRS 8)", https://ifrscommunity.com/knowledgebase/ifrs-8-operating-segments/\#link-alternative-management-performance-measures (Erişim tarihi: 02 Ocak 2021).

Paulech, Zuzana - Locke, Julie - Gladchenko, Oksana, (2020), Non-IFRS measures \& reshaping financial statement presentation.

PricewaterhouseCoopers - PwC, (2020), "Exposure draft ED/2019/7 Primary Financial Statements",

http://eifrs.ifrs.org/eifrs/comment_letters//554/554_26809_GaryBerchowitzPricewater houseCoopersPwC_0_PwCPFSCommentletterFINAL.pdf (Erişim tarihi: 03 Ocak 2021).

Ryan, Vincent, (2019), "IASB Proposes Changes To Reporting Of Profit And Income", https://www.cfo.com/gaap-ifrs/2019/12/iasb-proposes-changes-to-reporting-of-profitand-income (Erişim tarihi: 03 Ocak 2021).

Shearman \& Sterling LLP, (2020), "IASB Proposes Changes To Presentation And Disclosure Of IFRS Financial https://www.mondaq.com/unitedstates/CorporateCommercial-Law/890002/IASBProposes-Changes-To-Presentation-And-Disclosure-Of-IFRS-Financial-Statements (Erişim tarihi: 28 Aralık 2020).

Sheridan, Brendan - Hartwell, Michael - Holt, Oliver - McCarroll, John, (2020), "Financial Reporting 2020 - An 'exceptional' year", Deloitte Articles, https://www2.deloitte.com/ie/en/pages/audit/articles/financial-reporting-2020exceptional-year.html (Erişim tarihi: 02 Ocak 2021).

Sheridan, Brendan - McCarroll, John, (2020), "Corporate Reporting - Delivering The Message", https:/www2.deloitte.com/ie/en/pages/audit/articles/effective-corporatereporting-frb.html (Erişim tarihi: 02 Ocak 2021).

Sherman, H. David - Young, S. David, (2018), "The Pitfalls of Non-GAAP Metrics", MITSloan Management Review, 59(2), pp. 57-63.

Shibasaki, Yuta - Toyokura, Chikara, (2020), "The Disclosure Of Non-GAAP Performance Measures And The Adoption Of IFRS: Evidence From Japanese Firms' Experience", Monetary and Economic Studies, (38), pp. 19-54. 
Sivanantham, Siva, (2016), How to Make Your Financial Statements An Effective Communication Tool, CA ANZ Perspective.

Smith, Larry, (2018), Does FASB's New Performance Reporting Project Address What is Really Needed?, Accounting policy \& practice report: News archive (Bloomberg BNA Insights).

Stewart, Lindsey, (2020), "Changes to the Income Statement - What Do Investors Think?" https://home.kpmg/uk/en/home/insights/2020/10/changes-to-the-incomestatement.html (Erişim tarihi: 02 Ocak 2021).

Sultanoğlu, Banu, (2020), "Finansal Raporlamada Daha İyi İletişim: Uluslararası Muhasebe Standartları Kurulu'nun yaptığı çalışmalar", Muhasebe ve Denetime Bakış, (60), ss. 229-250.

Sweet, Pat, (2016), "IASB Chair Warns of “Misleading” Non-GAAP Metrics in Executive Remuneration", https://www.accountancydaily.co/iasb-chair-warns-misleading-nongaap-metrics-executive-remuneration (Erişim tarihi: 06 Ocak 2021).

The CPA Journal, (2018), Tax \& Accounting Update, News \& Views.

The Footnotes Analyst, (2020), "Disaggregation is key to Understanding Performance", https://www.footnotesanalyst.com/disaggregation-is-key-to-understandingperformance (Erişim tarihi: 08 Ocak 2021).

Thinggaard, Frank - Wagenhofer, Alfred - Evans, Lisa - Gebhardt, GüNther - Hoogendoorn, Martin - Marton, Jan - ... Peasnell, Ken (2006), "Performance reporting - the IASB's proposed formats of financial statements in the exposure draft of IAS 1", Accounting in Europe, 3(1), pp. 35-63, https://doi.org/10.1080/09638180600920152

Tokar, Mary - Kumar, Sid, (2020), "In brief: Applying IFRS Standards in 2020 - Impact of covid-19", $\quad$ https://cdn.ifrs.org/-/media/feature/news/2020/inbrief-covid19oct2020.pdf?la=en (Erişim tarihi: 06 Ocak 2021).

Treasury Board Secretariat, (2008), Performance reporting Principles And Guidelines.

Vatrenjak, Aida, (2019), Staff Paper - Amending Proposals For Management Performance Measures (MPMs). IASB Agenda ref 21A (Project: Primary Financial Statements).

Westworth Kemp, (2019), "For everything To Stay The Same, Everything Must Change News From The IFRS Conference", https://www.westworthkemp.com.au/blog/-foreverything-to-stay-the-same--everything-must-change----news-from-the-iasbconferene (Erişim tarihi: 07 Ocak 2021).

White, Sara, (2019), "IASB Plans To Prioritise Intangibles Reporting Under IFRS", accountancydaily.co/iasb-plans-prioritise-intangibles-reporting-under-ifrs (Erişim tarihi: 06 Ocak 2021).

Young, Steven, (2014), "The Drivers, Consequences And Policy İmplications Of Non-GAAP 
Earnings Reporting", Accounting and Business Research, 44(4), pp. 444-465, https://doi.org/10.1080/00014788.2014.900952 